\title{
COMPARATIVE ADVANTAGE AS A BARGAINING CHIP IN GLOBAL VALUE CHAIN: INDONESIA RATTAN INDUSTRY
}

\author{
SHAFITRI ARINDYA RAMADHANTY \\ Faculty of Business and Economics, Universitas Surabaya \\ arindyar13@gmail.com \\ DOI 10.31219/osf.io/8e9h5
}

Rattan is one of the significant yields of non-wood forest products (NWFPs) in international trade, which provides opportunities for climate change mitigation, reforestation, and sustainable forest management, as well as securing vital wildlife habitat and improving their livelihoods. As the top producer of rattan, Indonesia dominates rattan trade in the global market with abundant supply. The cultivation of rattan offers local communities and farmers in Kalimantan, Sumatera, Papua, and Sulawesi a source of income, a risk-management tool, a marker for land-holding, and a mean of saving (Pratono, 2019) (Sastry, 2001) (WWF, 2017) (INBAR, 2015). The tremendous annual sustainable production potential of 300,000 tonnes of rattan in Indonesia makes rattan an excellent source for national income and places Indonesia in the third position of rattan products exporter with an export value of USD 138 million and comprises $7.9 \%$ of the world's rattan export as of 2015 (INBAR, 2017).

Subsequently, the economic performance of Indonesia in terms of comparative advantage in the rattan industry is of great national importance, which can contribute to economic planning and socioeconomic development. It will result in economic efficiency gained from specialization. Since comparative advantage focuses on opportunity cost and is location-specific (Beaudreau, 2016), Indonesia gains the upper-hand because of its megadiverse nature; therefore, the abundant resources of rattan, sufficient technology, skill, knowledge, and considerably low cost for labor make it possible for the country to have a comparative advantage in rattan industry. Inevitably, other countries of Indochina such as Vietnam can also 
produce, process, and export rattan, be it raw materials, semi-finished products, or finished goods. However, a trade between two countries with mutual benefits are possible using the concept of comparative advantage. The relevancy of comparative advantage in the context of the rattan industry and trading comes from the fact that both countries are producers of rattan and rice. In fact, with the lower domestic prices for labor and rice-growing land in Vietnam, as well as ample resources of rattan in Indonesia, the two countries will gain mutual benefits if they trade these two goods with the basis of comparative advantage under the assumption that these two goods are consumed in the same and fixed proportions. In addition to fair trade terms and conditions agreed by both parties, the two countries can develop long-term trade relationship, which can affect their economic performance and garner friendly bilateral relationship between the countries. The differences in economy-wide supply conditions are the cause of the difference in relative autarky prices, hence the pattern of comparative advantage. Even when one country has the endowments of technology, skill, and lower labor cost for production, the country can still import despite its absolute advantage in the said production (Reinert, 2012).

Consequently, with comparative advantage Indonesia has over the world's rattan industry, the country can contribute to the Global Value Chain of rattan. According to Hernández and Pedersen in Global value chain configuration: A review and research agenda, Global Value Chain (GVC) can be defined as "the full range activities that one performs on a global scale to bring the product beyond their conception.". Global Value Chain (GVC) proposes the concept of governance and a chance to improve a country's position in the global economy. It introduces two concepts of governance and upgrading, which respectively refer to the organizational structure of Global Value Chain (GVC) and how firms (in this case is country) maintain or improve their position in the global economy (Golini, Caniato, \& Kalchschmidt, 2016) while acting as the driver for job creation, productivity growth, and increased living standards. With Global Value Chain (GVC) development, countries can import skills, grow faster, boost employment, and gains benefits through technology transfer (World Bank, 2020). This value chain concept proposes that 
the global economy is an integrated combination of input supply, trade, production, and final marketing (Gibbon \& Ponte, 2008). In the context of the Indonesian rattan industry, the governance structure of buyer-driven tends to promote fair trade more than other types of governance structure. It is because, in a developing country such as Indonesia, buyer-driven holds more opportunity to integrate with global market systems (Lessmeister, 2008) and this governance structure coincides with the shift of developing countries from Import Substitution Industrialization (ISI) to Export-oriented Industrialization (EOI) that was facilitated by the growth of export-processing zones in many developing countries. Export-oriented Industrialization (EOI) attracts 'light industries' (such as apparel, footwear, consumer electronics, consumer durables, fast-moving consumer goods, and furniture) since the barrier to entry is relatively low (Gereffi, 2001). With a low barrier to entry in production and a relatively high chance of integration in the global market, the industry of rattan in Indonesia will grow considerably and help in the movement of sustainable forest management while maintaining fair trade and contribute to economic planning of the country.

Therefore, the comparative advantage Indonesia gains from the rattan industry can be considered as a bargaining chip in Global Value Chain (GVC) and international trade as well as supporting the global economy as a whole. Still, the role of government and local communities in the industry holds the same importance in bringing rattan farmers and producers together. 


\section{References}

Beaudreau, B. C. (2016). Competitive and Comparative Advantage: Towards a Unified Theory of International Trade. International Economic Journal. doi:10.1080/10168737.2015.1136664

Gereffi, G. (2001, July). Beyond the Producer-Driven/Buyer-Driven Dichotomy: The Evolution of Global Value Chains in the Internet Era. IDS Bulletin, 32(3), 30-40. doi:10.1111/j.1759-

5436.2001.mp32003004.x

Gibbon, P., \& Ponte, S. (2008). Global value chains: from governance to governmentality? Economy and Society, 37(3), 365-392.

doi:http://dx.doi.org/10.1080/03085140802172680

Golini, R., Caniato, F., \& Kalchschmidt, M. (2016). Linking global value chains and supply chain management: evidence from the electric motors industry. Production Planning \& Control. doi:10.1080/09537287.2016.1170225

INBAR. (2015). Bamboo and Rattan for Climate Change. INBAR. Retrieved from https://bambuecuador.files.wordpress.com/2018/01/2015-inbarposition-paper-bamboo-and-rattan-for-climate-change.pdf

INBAR. (2017, January 13). INDONESIA. Retrieved from INBAR: https://www.inbar.int/country/indonesia/

Lessmeister, R. (2008). Governance and Organisational Structure in The Special Tourism Sector-Buyer-driven or Producer-driven value chains? : The case of trekking tourism in the Moroccan mountains. Erdkunde, 62(2), 143-157. Retrieved from https://pdfs.semanticscholar.org/0f4e/25eea0b798ed77659368f5f38 63636fd2a86.pdf

Pratono, A. H. (2019). Cross-cultural collaboration for inclusive global value chain: a case study of rattan industry. International Journal of Emerging Markets. doi:https://doi.org/10.1108/ IJOEM-01-2017-0028 
Reinert, K. A. (2012). AN INTRODUCTION TO INTERNATIONAL

ECONOMICS - New Perspectives on the World Economy (2nd ed.).

Cambridge University Press.

Sastry, C. B. (2001). Rattan in the twenty-first century - an overview.

An international journal of forestry and forest industries, 52(2).

Retrieved from Food and Agriculture Organization of the United

Nations.

World Bank. (2020). Global Value Chains. Retrieved April 3, 2020,

from World Bank: https://www.worldbank.org/en/topic/global-value-

chains

WWF. (2017, June 26). Rattan keeps forests standing in Borneo.

Retrieved April 3, 2020, from WWF:

https://wwf.panda.org/?303570/Rattan\%2Dkeeps\%2Dforests\%2Dsta

nding\%2Din\%2DBorneo 